\title{
Bone Metabolism: a Note on the Significance of Mouse Models
}

\author{
O. RAŠKA ${ }^{1}$, K. BERNÁŠKOVÁ ${ }^{1}$, I. RAŠKA JR. ${ }^{2}$
}

${ }^{1}$ Department of Normal, Pathological and Clinical Physiology, Third Faculty of Medicine, Charles University, ${ }^{2}$ Third Department of Internal Medicine, First Faculty of Medicine, Charles University, Prague, Czech Republic

Received November 27, 2007

Accepted July 21, 2008

On-line July 25, 2008

\section{Summary}

This minireview briefly surveys the complexity of regulations governing the bone metabolism. The impact of clinical studies devoted to osteoporosis is briefly summarized and the emphasis is put on the significance of experimental mouse models based on an extensive use of genetically modified animals. Despite possible arising drawbacks, the studies in mice are of prime importance for expanding our knowledge on bone metabolism. With respect to human physiology and medicine, one should be always aware of possible limitations as the experimental results may not be, or may be only to some extent, transposed to humans. If applicable to humans, results obtained in mice provide new clues for assessing unforeseen treatment strategies for patients. A recent publication representing in our opinion the important breakthrough in the field of bone metabolism in mice is commented in detail. It provides an evidence that skeleton is endocrine organ that affects energy metabolism and osteocalcin, a protein specifically synthesized and secreted by osteoblasts, is a hormone involved. If confirmed by other groups and applicable to humans, this study provides the awaited connection of long duration between bone disorders on one hand and obesity and diabetes on the other.

\section{Key words}

Bone remodeling - Osteoblast • Osteoclast • Osteoporosis • Osteocalcin • Obesity • Diabetes

\section{Corresponding author}

O. Raška, Third Faculty of Medicine, Charles University, Ke Karlovu 2, 12000 Prague 2, Czech Republic. E-mail: raskaota@seznam.cz

\section{Introduction}

Osteoporosis became a pandemic disease of the mankind with extensive health care and social demands (Raška and Broulík 2005, Teitelbaum 2007, Hofbauer et al. 2007). Based on the extensive statistics, particularly from countries in which convenient surveillance program is being implemented, a very high percentage of elderly people, particularly women after menopause, experience an osteoporotic fracture frequently accompanied by the debilitating fate of the patient (Štěpán et al. 2003, Teitelbaum 2007). Despite an enormous progress of our knowledge, due to both clinical and experimental results achieved in the last 10 years (Boyle et al. 2003, Harada and Rodan 2003, Karsenty 2006, Teitelbaum 2007, Teitelbaum and Ross 2003, Zaidi 2007), a synthetic view on the molecular mechanisms responsible for the etiopathology of the disease is still missing. This lack of knowledge should be attributed to a very complex, systemic regulation of the bone homeostasis that is reflected through the bone remodeling. The remodeling is a dynamic metabolic process that serves not only for the adjustment of the bone architecture to meet changing mechanical needs. It is important in maintaining plasma calcium homeostasis including reversible changes accompanying lactation period, it serves to adjust the biological parameters of the bone cellular elements and it helps to repair (micro)damage in the bone matrix (Štěpán et al. 2003, Woodrow et al. 2006).

Skeleton is a dynamic organ. It comprises of two types of bone: cortical and trabecular. Although both types are being continuously remodeled during human life-time, there is a much higher turnover in the trabecular 
bone. Two different cell lineages serve distinct skeletal functions in the bone remodeling. Osteoblasts are derived from bone marrow mesenchymal stem cells, and construct and shape the skeleton for optimal performance. The osteoclasts, which are derived from the hematopoietic stem cells, resorb the bone and contribute to the maintenance of mineral homeostasis. The highly regulated balance, in time and space, between bone deposition and resorption (a relationship known as coupling) is crucial for the proper development and maintenance of bone size, shape and integrity. It is affected through the differentiation and functions of osteoclasts and osteoblasts that are determined not only by a high number of cytokines acting locally as well as by a direct communication between the two types of cells, but also by a multitude of hormones acting in a systemic way (Zaidi 2007, Cirmanová et al. 2008).

Wwe should mention here obesity and diabetes mellitus as these also represent pandemic dangers that similarly to osteoporosis arose only in the 20th century. Obesity represents a disorder of energy metabolism that predisposes to diabetes, hypertension, and hyperlipidemia, diseases characterized by insulin resistance and complicated by atherosclerosis (Adams et al. 2006, Semenkovich 2006, Semenkovich and Teitelbaum 2007). Diabetic patients suffer from various bone disorders, and osteoporosis is the most frequent metabolic bone disorder (Hofbauer et al. 2007, Raška and Broulík 2005). Both type 1 and type 2 diabetes are apparently associated with increased risk of bone fractures, although only type 1 diabetes is associated with lower bone density (Schwartz and Sellmeyer 2007). It has been generally believed that diabetes, through increased levels of blood glucose and decreased levels or effectiveness of insulin and insulin-like growth factor (IGF)-1, affects negatively osteoblast activity, and thus may play a role in osteoporosis (Inaba 2004).

In this minireview, we shall first shortly survey the possibilities of clinical studies dealing with osteoporosis, the significance of the experimental mouse model and the complexity of the bone metabolism. We shall then highlight a recent contribution describing endocrine function of skeleton and coupling regulation of bone and energy metabolism (Lee et al. 2007) the results of which, if confirmed by other groups, represent the breakthrough in the field of bone metabolism. In addition, if applicable to humans, this study provides a link between bone misfunctioning on one hand and obesity and diabetes on the other.

\section{Clinical studies and the significance of experimental mouse models}

Clinical studies dealing with osteoporosis can be in the first approximation divided in two categories, one with the aim to prevent catabolic resorptive processes in the bone, and the other in which anabolic processes are potentiated in order to enhance the bone formation (Canalis et al. 2007, Štěpán et al. 2003). Although such a division seems to be artificial, due to an extensive crosstalk of various metabolic pathways as well as systems feedback loops involved, in practical terms it represents a convenient scheme for the treatment. We should also mention here the importance of clinical studies involving patients with established polymorphisms (mutations) in the genes involved directly or indirectly in the bone metabolism (Kř́žová et al. 2007, Liu et al. 2006).

Osteoporosis is a multigenic and multifaceted metabolic disease, with dozens of identified genes being involved, and results from the interplay between genetic and environmental factors that also involve daily habits of an individual (Canalis et al. 2007, Liu et al. 2006, Stepan et al. 2003, Teitelbaum 2007). Imbalances of bone remodeling can result in smaller or larger perturbations in skeletal structure and function, and potentially in diseases like osteoporosis. Therefore, already its prevention is of utmost importance.

Each patient suffering from osteoporosis frequently exhibits pleiotropic symptoms. An individual patient, representing a very specific entity, can respond to a given treatment differently with regard to another patient exhibiting the same manifestations of the disease. This difficulty is to a large extent surmounted by doubleblind long-term studies involving a large number of persons. Such clinical studies of irreplaceable importance provide treatment schemes and define also respective dangers ensuing from the use of individual tested drugs (Canalis et al. 2007, Štěpán et al. 2003). On the other hand, such studies may also exhibit a drawback. In practical terms, the most proper control group does not exist since it is ethically difficult or even impossible not to medicate the patients from the control group in longterm studies.

The limitations of clinical studies are to be identified with the nature of the results obtained. In human medicine, we are usually limited to the investigation of the bone mineral density (BMD) and a measure of relevant biological markers in serum and urine (Zikán and Štěpán 2002). Consequently, these 
phenomenological studies cannot provide information about the molecular processes taking place in various tissues or organs, including the bone, that are to be identified as genuine players responsible for the etiopathogenesis of the disease. Moreover, the results obtained by different research groups are not always completely comparable. For this purpose, for instance, the same choice of the site in a given bone for BMD evaluation should be used by all research groups. But BMD data alone may not necessarily provide the proper information about bone structure or strength (Zaidi 2007).

In contrast to clinical studies, mouse models allow the investigation of molecular processes within the frame of bone remodeling and their use potentially permits to experimentally prove/disproof proposed specific hypotheses addressing the bone metabolism. Importantly in this respect, skeleton is a late acquisition during development (Karsenty 2006). This explains why a high degree of conservation of relevant factors (regulatory molecules such as transcription factors, kinases, receptors, secreted molecules, or structural proteins) frequently exists between mice and humans. Due to the endeavor of tens of experimental laboratories exploring transgenic rodents, particularly mice, we witness today an enormous progress in the knowledge of bone metabolism and its (experimentally induced) disorders. At the same time, possible drawbacks of the results obtained have to be emphasized. Physiology of genetically modified animals may be biased due to adaptive and other changes ensuing from a partial or complete lack of the relevant gene, or from overexpressed genes in mice in which genes were knocked in. Importantly, the experimental results obtained may not be transposed, or transposed only to a limited extent, to humans.

The regulation of bone metabolism is complex (see e.g. Fig. 1 in Cirmanová et al. 2008 and Fig. 2 in Gallo et al. 2008). Frequent cross-talks in regulatory pathways, accompanied by signal divergence, do occur and feedback loops modulate the whole system. In this context, the experimental approaches with mice have been largely refined. Accordingly, genes to be investigated are either knocked in, knocked out, conditionally knocked out or their expression is modulated, but frequently only in the target cell types within a given organ, such as bone. Always bearing in mind the inherent drawbacks of the genetically modified animal model, direct involvement of specific molecular processes can thus be potentially pinned down with a limited interference from the various regulatory pathways or even the whole system.

\section{Survey of the regulation of bone metabolism}

The regulation of bone metabolism may be categorized from various points of view such as proosteogenic and antiosteogenic or local and systemic, including both neuronal and humoral subcategories; we shall stick here to the latter one. This chosen categorization of regulations represents a simplified view since some pathways exhibit both systemic and local features (see Fig 1. in Cirmanová et al. 2008) such as leptin pathways (see below). We have to emphasize that our knowledge of regulation comes from two, not always reconcilable sources, human medicine and experiments with animal models. Accordingly, although leptin significance has not yet been proven in a convenient way in humans, leptin is without any doubt an important regulator of bone remodeling in mice (Karsenty 2006).

Contemporary literature usually divides systemic bone regulation into two main subcategories, the recently discovered neuronal and the already well-known humoral regulations. The moment which led to such a new view on the systemic regulation of bone metabolism was the discovery that leptin, an important regulator of energy metabolism (Zhang et al. 1994), regulates also bone remodeling through a hypothalamic relay in mice and that action of leptin on bone formation through this hypothalamic relay is mainly inhibitory (Ducy et al. 2000). Subsequent studies revealed that sympathetic nervous system (SNS) is one of the major effectors of this relay, and that its action on bone is accomplished through $\beta_{2}$-adrenergic receptors present on osteoblasts (Takeda et al. 2002). When these receptors are activated, they trigger within the osteoblast two different downstream molecular cascades, first cascade affects the clock genes and inhibits osteoblast proliferation, second cascade promotes receptor activator of nuclear factor- $\kappa \mathrm{B}$ ligand (RANKL; see below) secretion and thereby increases osteoclastogenesis (Elefteriou et al. 2005, Fu et al. 2005). Therefore, in the first approximation, one may say that the increase of sympathetic activity through the central leptinonergic pathway leads to decreased bone formation and also increased bone resorption.

Furthermore, the egress of hematopoietic stem cell precursors of the osteoclast lineage from the hematopoietic stem cell niche was also found to be controlled by adrenergic signaling through the osteoblasts 
(Katayama et al. 2006, Zaidi 2007).

Importantly, leptin also centrally stimulates expression of anorexogenic hypothalamic neuropeptide called cocaine- and amphetamine-regulated transcript (CART) (Elefteriou et al. 2005). As result, RANKL expression is, via an unknown mechanism, downregulated in osteoblasts and bone resorption is thus decreased (Cirmanová et al. 2008, Elefteriou et al. 2005, Karsenty 2006). Therefore leptin seems to centrally regulate bone resorption in two opposite ways. First, leptin stimulates bone resorption through the leptin/SNS pathway. Second, leptin inhibits bone resorption through CART expression (Cirmanová et al. 2008, Karsenty 2006). Moreover, it has been recently shown that CART apparently acts more as a circulating hormone than a neuropeptide (Singh et al. 2008).

Within the context of hypothalamic regulations, two other hypothalamic neuropeptides, neuropeptide $\mathrm{Y}$ (NPY) and neuromedin U (NMU), apparently regulate not only energy metabolism but also bone mass. Neuropeptide $\mathrm{Y}$ is expressed in the central nervous system as well as in peripheral tissues. There are several types of Y receptors present in all kinds of tissues. Both bone and adipose tissues are known to be centrally regulated by hypothalamic Y2 receptors and the mice with knocked out Y2 gene exhibit increased bone mass (Lundberg et al. 2007). Osteoblastic cells express Y1receptors and the deletion of the relevant leads to increased bone and adipose mass (Baldock et al. 2007). Neuromedin U, an anorexogenic neuropeptide, has been recently identified as a potent regulator of bone formation and NMU deficient mice showed increased bone formation (Sato et al. 2007). Leptin intracerebroventricular infusions or $\beta_{2}$-adrenergic agonist treatment in NMU-deficient mice did not show any decrease in bone mass and bone formation. Moreover, expression of molecular clock genes was downregulated in NMUdeficient mice. These data indicate that NMU could be a central mediator of the leptin-dependent regulation of bone mass (Sato et al. 2007).

In addition to leptin, the humoral action of which is commented within the microenvironmental context (see below), humoral control of bone remodeling encompasses many well-known hormones. Parathyroid hormone $(\mathrm{PTH})$ is the most important regulator of calcium metabolism and its continuous secretion is a potent stimulator of bone resorption (Bisello et al. 2004). PTH increases renal reabsorption of calcium and excretion of phosphates and also stimulates renal calcitriol production (Mundy and Guise 1999). On the other hand, if PTH is secreted or administered intermittently it acts as a potent anabolic bone agent (Neer et al. 2001). The molecular basis of this effect is still not clearly understood, but the recent experiments show that the increase of osteoblast number is due to the ability of intermittent PTH to delay osteoblast apoptosis (Jilka et al. 1999, Martin et al. 2006). Calcitriol is essential in increasing the intestinal absorption of calcium and phosphates (Mundy and Guise 1999). The ablation experiments with vitamin D receptor show that the effects of calcitriol on the bone metabolism are indirect through changes of the calcium level (Demay 2006). Growth hormone $(\mathrm{GH})$ is anabolic, but its action is mainly indirect, through secreting IGF-1, which represents the active physiological stimulator of bone formation (Yakar et al. 2002, Zhang et al. 2002). Genetic deficiency of IGF-1 causes growth retardation and osteopenia, and this bone loss is not rescued by GH administration (Zaidi 2007). Glucocorticoids (GCs) have very complex effect on bone, but there is no doubt that the excess of GCs, which is encountered during long-term glucocorticoid therapy, has suppressive effect on bone formation (Weinstein 2001, Weinstein et al. 1998). Recently, it has been shown that osteoclasts are the intermediary cells, which are necessary for glucocorticoid-induced osteoblast inhibition (Kim et al. 2006). However, the glucocorticoid-induced osteoclast-to-osteoblast signal still remains to be identified. Furthermore, GCs directly target mature osteoclasts and specifically disrupt their cytoskeleton (Kim et al. 2006). Such a disruption restricts bone resorption and therefore also retards bone remodeling, and thus decreases bone formation. The retarded remodeling, which is characteristic for long-term GC therapy, leads to brittleness of the bones. This raises an argument that for an effective prevention of skeletal complications in long-term GC therapy, some restoration of osteoclast activity is required (Teitelbaum 2007). In contrast, the reason why there is a transient increase in bone resorption during short-term GC treatment is unknown (Dovio et al. 2004). Simple explanation of the effect of short-term GC therapy could be through overriding pro-resorptive effect of inflammatory cytokines, which are abundant in GC-treated diseases such as autoimmune ones (Teitelbaum 2007). As these inflammatory cytokines decrease during long-term GC therapy, the suppressive effect of GCs on osteoresorption becomes apparent (Teitelbaum 2007). Calcitonin is an important hormone during pregnancy and particularly 
lactation because it protects the bone against the demineralizating effects of estrogen deficiency and increased levels of mammary-secreted parathyroid hormone-related protein (PTHrp; see below) during this life period (Woodrow et al. 2006). Its exact role in the adult skeleton is still to be determined. Although there is a clear receptor-mediated inhibitory effect on osteoclasts, experimental ablations of calcitonin gene lead to a high bone mass rather than to osteopenia (Hoff et al. 2002, Zaidi 2007). Thyroid hormones have anabolic effects on bone during growth. Their lack during growth results in delayed ossification and bone mineralization (Bassett et al. 2008, Bassett et al. 2007a). In contrast their excess in adults, which is seen during e.g. thyrotoxicosis, causes osteoporosis (Bassett et al. 2007a,b). Androgens act through androgen receptors (ARs), which are present in both osteoblasts and osteoclasts. Their action is essential for normal skeletal development and preservation of bone mass (Sato et al. 2002). The experiments with AR ablation result in an increased bone resorption in male mice. AR ablation in female mice does not notably affect the bone metabolism possibly because of the dominant role of estrogen receptors (Kawano et al. 2003, Nakamura et al. 2007). Estrogens (ES) play a key role in the control of bone mass (Manolagas et al. 2002). They stimulate osteoblast proliferation and decrease their apoptosis (Kousteni et al. 2002). They reduce the effect of RANKL in the osteoclast precursors and impair the osteoclast formation (Srivastava et al. 2001). ES also induce apoptosis in bone-resorbing osteoclasts (Kameda et al. 1997, Kousteni et al. 2002). Decrease of ES, which is seen after menopause, causes osteoporosis in a significant number of women. Until lately, bone response to ES withdrawal has been understood as a complex reaction of inflammatory and osteoclastogenic cytokines in which osteoblasts were the primary estrogen targets (Clowes et al. 2005). Importantly, two recent publications using transgenic mice have shed a new light on molecular mechanisms governing ES protection of bone (Nakamura et al. 2007, Krum et al. 2008). Apoptic Fas ligand (FasL) gene, being under control of estrogen receptor $\alpha(\operatorname{ER} \alpha)$, is the key player, but its activation was shown to take place either in osteoclasts (Nakamura et al. 2007) or in osteoblasts (Krum et al. 2008). In the first case, it is shown that ES induces the activation of the FasL gene in an autocrine manner. This activation then leads to suppression of bone resorption through apoptosis of differentiated osteoclasts (Nakamura et al. 2007). In contrast, Krum et al. (2008) described a paracrine mechanism in which ES affects osteoclast survival through the upregulation of FasL in osteoblasts (and not osteoclasts). This leads to an induction of a paracrine signal originating in osteoblasts that results in apoptosis of pre-osteoclasts. The FasL is identified as the key gene in both cases, but further work is needed to establish which mechanism really applies. The action of thyroid stimulating hormone (TSH) and follicle stimulating hormone (FSH) has been considered as indirect through the action of thyroid and gonadal hormones (Zaidi 2007). Recent reports suggest, however, that TSH and FSH have also direct effect on bone cells that overrides the effect of thyroid and gonadal hormones (Abe et al. 2003, Sun et al. 2006). Both hormones apparently interact reciprocally with MAP kinases, nuclear factor- $\mathrm{B}$ and Akt kinases downstream of RANKL. In addition, both TSH and FSH probably also function in a reciprocal manner via tumor necrosis factor (TNF)- $\alpha$ as the downstream mediator (Hase et al. 2006, Iqbal et al. 2006). However, some of the recent results do not support this dominant effect of FSH and TSH (Bassett et al. 2007b, Bassett et al. 2008, Nakamura et al. 2007) and thus further research needs to be performed to clarify this issue.

The second category of regulations involves local regulations within the bone microenvironment in which the molecular cross-talk between bone cell types, bone and immune cell types, but in the first row the cross-talk between osteoclasts and osteoblasts, is the primary mechanism regulating bone remodeling. The central role of the cross-talk is played by the RANKL/RANK/OPG system, where RANK stands for receptor activator of nuclear factor- $\kappa \mathrm{B}$ and $\mathrm{OPG}$ for osteoprotegerin (Boyle et al. 2003, Khosla 2001). Osteoblasts, stromal stem cells and activated immune cells express RANKL, which is a cytokine from the TNF superfamily and its action is to activate RANK receptors on osteoclasts or their precursors. After the RANK receptors are activated, they promote activation and survival of osteoclasts or differentiation of osteoclast precursors, and thus lead to osteoresorption. This action of RANKL is inhibited by OPG which is a decoy receptor and is also released from osteoblasts and osteogenic stromal cells, and RANKL/OPG ratio controls the degree of bone resorption (Boyle et al. 2003, Hofbauer et al. 2000, Khosla 2001). Although some cytokines and hormones can control bone resorption and formation directly, many of them control it by modulating the RANKL/RANK/OPG system (Boyle et al. 2003). For example, TNF- $\alpha$, a potent osteoclastogenic cytokine, 
stimulates osteoblast production of RANKL and also acts directly on osteoclasts and their precursors in an osteoclastogenic manner. The osteoclastogenic action of interleukin (IL)-7 is now explained by promoting proliferation of T-cells and their secretion of TNF- $\alpha$ and RANKL (Clowes et al. 2005). Macrophage colony stimulating factor is indispensable during normal differentiation of osteoclasts and its deficiency impairs osteoclastogenesis. Interferon (IFN) $-\gamma$ in inflammatory conditions blocks RANKL-mediated osteoclastogenesis. In summary, TNF- $\alpha$, IL-7 (as well as IL-6) and RANKL seem to be pro-osteoclastogenic, IFN- $\gamma$ and OPG (as well as IL-4, IL-10 and transforming growth factor- $\beta$ ) seem to inhibit osteoclastogenesis (Clowes et al. 2005, Zaidi 2007).

Recent studies define local intermittent production of PTHrp by early osteoblast progenitors and osteocytes as a crucial endogenous anabolic factor, which supports osteoblast differentiation and survival, and thus bone formation (Bisello et al. 2004, Kronenberg 2006, Miao et al. 2005). Moreover, intermittent administration of PTHrp to patients is also anabolic (Horwitz et al. 2003). In contrast, although apparently not within the microenvironmental context, prolongated and elevated levels of PTHrp seen under specific physiological conditions (lactation) or malignancies, has been shown to support osteoclastogenesis and bone resorption (Bisello et al. 2004, Broadus et al. 1988, Jilka 2007, Kronenberg 2006, Woodrow et al. 2006).

Concerning peripheral action of leptin, it should be noted that both humoral and local effects take apparently place as adipocytes in bone marrow also secrete leptin (Laharrague et al. 1998). Leptin receptors have been shown to be present in a large number of peripheral tissues, including cell elements in bone (Cirmanová et al. 2008, Zhang et al. 2005). With respect to its action, several studies support a concept that the effect of leptin within the bone microenvironment is likely proosteogenic (Burguera et al. 2001, Cornish et al. 2002, Holloway et al. 2002, Khosla 2002, Thomas et al. 1999). In contrast to central effect of leptin, its local effect seems to be realized via upregulation of OPG pathway (Burguera et al. 2001, Holloway et al. 2002), although the involvement of other pathways cannot be excluded. It should be noted, however, that several reports questioned the importance of the direct leptin effect on bone (Astudillo et al. 2008, Ducy et al. 2000, Patel and Elefteriou 2007, Takeda et al. 2002).

Finally, we have to mention the ubiquitous effect of mechanical stimuli which is essential for the maintenance of skeletal mass. Quintessence of this effect is the transduction of mechanical signals into the cell, termed mechanotransduction, which then regulates expression of various genes (Liedert et al. 2006, Zaidi 2007).

We conclude this short survey on regulations of bone metabolism with a prologue to the next subchapter. It appears that bone metabolism and metabolism of nutrients have many common regulatory mechanisms involving e.g. GH, corticoids, leptin, NPY and NMU, TNF- $\alpha$, CART. As obesity protects mammals from osteoporosis (Tremollieres et al. 1993), Karsenty and collaborators (Ducy et al. 2000, Karsenty 2006) proposed that bone remodeling and energy metabolism could be regulated by the same hormone(s). They indeed showed that leptin affects the bone in mice (Karsenty 2006). Most hormonal regulations are controlled by feedback loops such that a cell type affected by a hormone sends signals influencing the hormone producing cell. If indeed bone cells influcence the level of activity of hormoneproducing cells, then osteoblasts should strike back and affect energy metabolism.

\section{Bone is endocrine organ regulating energy metabolism}

To identify osteoblast-enriched genes affecting energy metabolism, Karsenty and collaborators (Lee et al. 2007) generated mutant mouse strains lacking genes encoding signaling molecules expressed only or preferentially in osteoblasts. Through this effort they inactivated in an osteoblast-specific manner Esp, a gene expressed just in osteoblasts and Sertoli cells, that encodes a receptor-like protein tyrosine phosphatase termed osteotesticular protein tyrosine phosphatase (OST-PTP) (Morrison and Mauro 2000, Schiller and Mauro 2005). Mice lacking OST-PTP (Esp mice) were shown to be hypoglycemic and to have increased $\beta$-cell proliferation and insulin secretion, increased insulin sensitivity, higher adiponection production, higher energy expenditure, lower visceral fat, and were protected from obesity and glucose intolerance (Lee et al. 2007). Ex vivo co-culture experiments showed that osteoblasts from Esp mice increased insulin expression in islets of Langerhans and an insulin-sensitizing adipokine, adiponectin (Otabe et al. 2007, Yamauchi et al. 2001), expression in adipocytes. In contrast, in transgenic mice overexpressing Esp gene selectively in osteoblasts, the metabolic and 


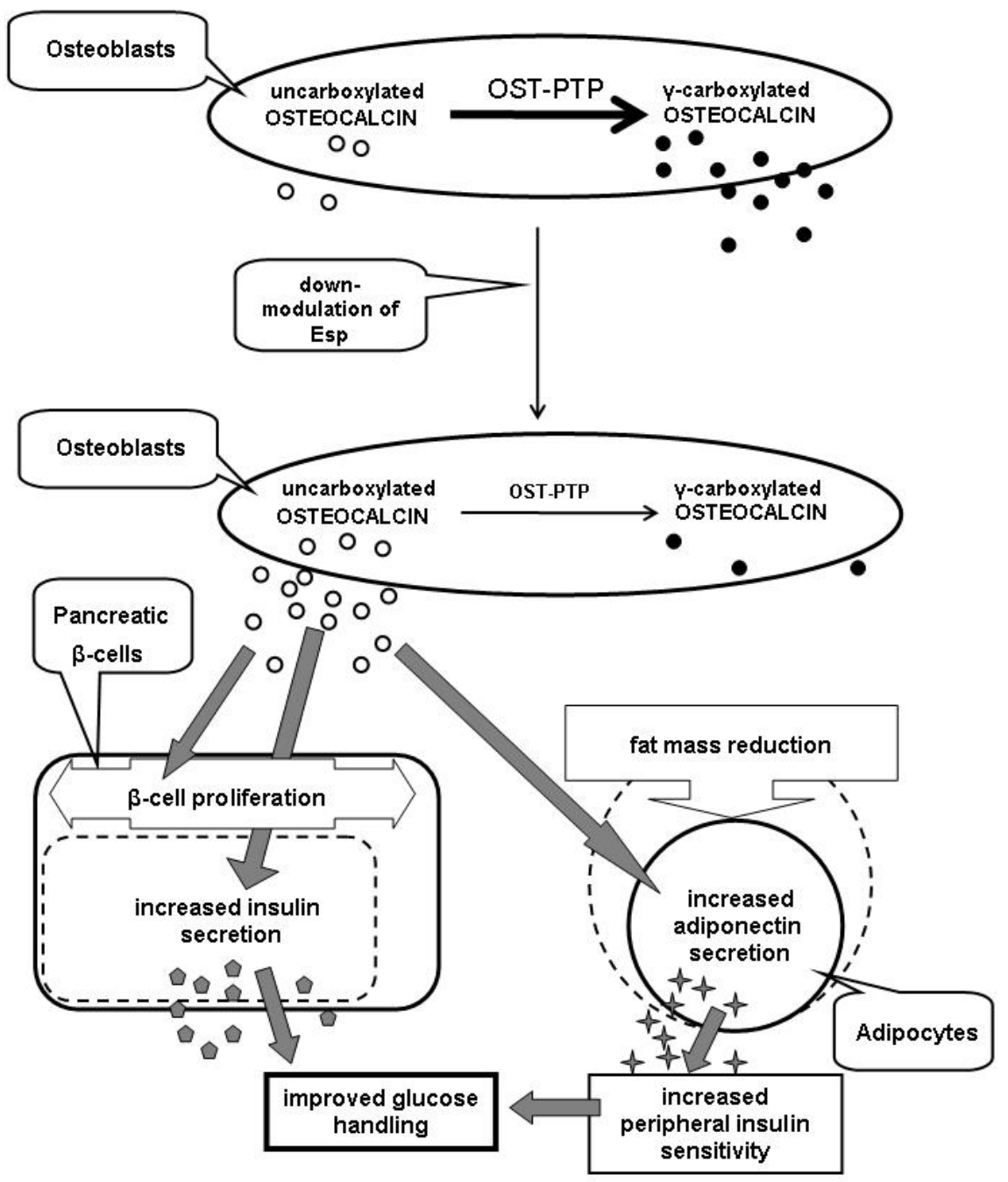

Fig. 1. Osteoblasts affect energy metabolism via uncarboxylated osteocalcin. Osteoblastic Esp gene encodes OST-PTP protein that favors, through an unknown mechanism, a modification of osteocalcin, an osteoblast-specific protein. This modification consists of the $\mathrm{Y}$-carboxylation of osteocalcin. Uncarboxylated osteocalcin ( $\mathrm{O}$ ), but not $y$-carboxylated osteocalcin (0), affects energy metabolism. Downmodulation of Esp gene leads to an increased level of secreted uncarboxylated osteocalcin by osteoblasts. Secreted uncarboxylated osteocalcin affects pancreatic $\beta$-cells and adipocytes. As the result, $\beta$-cell proliferation as well as insulin (-) and adiponection ( + ) secretion are increased. This leads to increased peripheral insulin sensitivity and improved glucose handling. proliferation parameters seen in Esp mice were reversed. OST-PTP thus controls downstream the bioactivity of an osteoblast-derived secreted molecule regulating adiponectin as well as insulin expression, and glucose homeostasis.

In the search for such an osteoblast secreted molecule, Lee et al. (2007) focused on osteocalcin since mice lacking gene $O c n$ for osteocalcin (Ocn mice) are obese. Osteocalcin has several features of a hormone as it is cell-specific molecule, synthesized as a prepromolecule and secreted (Hauschka et al. 1989, Price 1989). Osteocalcin may also undergo, via the action of OST-PTP, a posttranslational modification whereby its glutamic acid residues are carboxylated to form $\gamma$-carboxyglutamic acid (Gla) residues (Hauschka et al. 1989).

The phenotype of Ocn mice, with decreased $\beta$-cell proliferation and energy expenditure and increased insulin resistance, was exactly the opposite of Esp mice. However, in experiments in which Ocn mice were administered glucose together with recombinant osteocalcin, i.e. non-Gla modified protein, they were rescued as decreased glucose levels and increased secretion of insulin were seen. Moreover, ex vivo, non-Gla modified osteocalcin stimulated cyclin D1, a molecular marker of cell proliferation (Kushner et al. 2005), and insulin expression, in islet $\beta$-cells, and adiponectin in adipocytes. Thus, although Lee et al. (2007) did not exclude the participation of other secreted osteoblast-specific molecules, they provided evidence that osteocalcin regulated the glucose level (Fig. 1).

The production and clearance of osteocalcin were normal in Esp mice, so that OST-PTP did not regulate Ocn gene expression (Lee et al. 2007). The results obtained thus suggested that in Esp mice, there was a gain of osteocalcin metabolic activity. Most importantly, this was demonstrated as Esp mice being heterozygous for Ocn exhibited a remarkable reversal of all their metabolic characteristics, and $\beta$-cell proliferation 
was reduced in these mice. In addition, if normal osteoblasts were co-cultured with adipocytes treated with warfarin, an inhibitor of $\gamma$-carboxylation (Berkner 2005), a substantial increase of adiponectin expression was observed. All together, these results provided an evidence that Esp and Ocn lied in the same regulatory pathway, showed that OSP-PTP, via the $\gamma$-carboxylation, downregulated the metabolic bioactivity of osteocalcin, and established a link between bone and energy metabolism, both in wild type and transgenic mice (Fig. 1) (Ferron et al. 2008, Lee et al. 2007). Furthermore, Ferron et al. (2008) provided evidence that osteocalcin differentially regulates $\beta$-cell and adipocyte gene expression and that continuous administration of osteocalcin acts in wild type mice to improve glucose handling and reduce fat mass, and that, as a result, it can reduce the severity of obesity and type 2 diabetes.

\section{Concluding remarks}

We provided here a short survey on the impact of clinical studies devoted to osteoporosis and the complexity of regulations governing the bone metabolism. We emphasized the significance of the experimental mouse model. Despite possible drawbacks ensuing from the use of knocked out and transgenic animals, the mouse model is of prime importance for expanding our knowledge on bone metabolism.

We commented here in detail the recent study (Lee et al. 2007) that, if confirmed by other groups, represents the real breakthrough in the field of bone metabolism. The results obtained demonstrated a new regulatory pathway and for the first time "closed" the circle - adipocytes and $\beta$-cells had been known to talk to bone, but Lee et al. (2007) have shown that bone was talking back. However, many important facets of this conversation are still to be elucidated. For instance, osteocalcin interacting partners in target cells/tissues have to be characterized and hiearchy of ensuing regulations to be established. In fact, the exact interrelationship between bone regulating energy metabolism via osteocalcin and feedback hormonal loop(s) is not known. It is not known through which regulation pathway leptin strikes back onto the regulation by osteocalcin, how osteoblasts "sense" the necessity to regulate energy metabolism and what are mechanisms leading to Gla-modification of osteocalcin and secretion of non-Gla modified osteocalcin.

Most importantly, until the experimental results
(Lee et al. 2007) are proven to apply in humans, they cannot be directly applied to human physiology and medicine. Interestingly, non Gla-modified osteocalcin was shown to reduce the severity diabetes 2 in mice (Ferron et al. 2008) and it should be noted that diabetic patients exhibit lowered osteocalcin levels (Gerdhem et al. 2005, Rosato et al. 1998). However, a protein tyrosine phosphatase, performing the modification of osteocalcin, remains to be identified in humans (Cousin et al. 2004, Schiller and Mauro 2005).

If the results of Lee et al. (2007) are applicable to humans, the link between bone metabolism and osteoporosis on one hand and obesity and diabetes on the other becomes apparent. Consequenly, the pathogenesis of some degenerative diseases of energy metabolism may then be more complex than anticipated. Accordingly, new schemes for treating obesity, diabetes, and their complications may apply (Semenkovich and Teitelbaum 2007). OSP-PTP is, for the time being, known to be produced just in osteoblasts and Sertoli cells, the pharmacological downmodulation of relevant human tyrosine phosphatase levels could be the straightforward approach. The use of warfarine (Berkner 2005) is also to be considered as it was up to now used to reduce the risk of thrombosis, but a systematic assessment of glucose metabolism and adiposity in these patients was not performed. Next, biphosphonate treatment affects osteoclasts, but decreased osteocalcin levels ensue from such therapy (Greenspan et al. 2005, Semenkovich and Teitelbaum 2007). Also, glucocorticoid therapy is common and predisposes patients to both diabetes and osteoporosis. Chronic administration of steroids affects osteoclasts and osteoblasts, suppressing bone formation and thus osteocalcin expression (Kim et al. 2006, Semenkovich and Teitelbaum 2007).

Witnessing today's exponential expansion of our knowledge of bone metabolism arising from the use of mice models, we are confident that many persisting questions will be answered in the near future. We hope that this will apply, even though in a longer run, with respect to questions relevant to human physiology and medicine.

\section{Conflict of Interest}

There is no conflict of interest.

\section{Acknowledgements}

We thank Jan Mareš, Ivan Raška and Vít Zikán for discussion. Because of the lack of space, we apologize 
to the authors the original studies of which were not cited. This work was supported by grants LC535, MSM 0021620807 and IGA MH CR 10564-3.

\section{Abbreviations}

AR - androgen receptor; Akt kinase - serine/threonine protein kinase; BMD - bone mass density; CART cocaine- and amphetamine-regulated transcript; ER estrogen receptor; ES - estrogens; Esp - gene coding OSP-PTP; Esp mice - mice with knocked out OSP-PTP gene; FasL - fibroblast-associated surface antigen ligand; FSH - follicle stimulating hormone; GC - glucocorticoid;
GH - growth hormone; Gla - $\gamma$-carboxyglutamic acid modification; IGF - insulin-like growth factor; IL interleukin; MAP kinase - mitogen activated protein kinase; NMU - neuromedin; NPY - neuropeptide Y; Ocn - osteocalcin gene; Ocn mice - mice with knocked out osteocalcin gene; OPG - osteoprotegerin; OST-PTP osteotesticular protein tyrosine phosphatase; PTH parathyroid hormone; PTHrp - parathyroid hormonerelated protein; RANK - receptor activator of nuclear factor- $\kappa \mathrm{B}$; RANKL - RANK ligand; SNS - sympathetic nervous system; TNF - tumor necrosis factor; TSH thyroid stimulating hormone.

\section{References}

ABE E, MARIANS RC, YU W, WU XB, ANDO T, LI Y, IQBAL J, ELDEIRY L, RAJENDREN G, BLAIR HC, DAVIES TF, ZAIDI M: TSH is a negative regulator of skeletal remodeling. Cell 115: 151-162, 2003.

ADAMS KF, SCHATZKIN A, HARRIS TB, KIPNIS V, MOUW T, BALLARD-BARBASH R, HOLLENBECK A, LEITZMANN MF: Overweight, obesity, and mortality in a large prospective cohort of persons 50 to 71 years old. $N$ Engl J Med 355: 763-778, 2006.

ASTUDILLO P, RIOS S, PASTENES L, PINO AM, RODRIGUEZ JP: Increased adipogenesis of osteoporotic humanmesenchymal stem cells (MSCs) characterizes by impaired leptin action. J Cell Biochem 103: 1054-1065, 2008.

BALDOCK PA, ALLISON SJ, LUNDBERG P, LEE NJ, SLACK K, LIN EJ, ENRIQUEZ RF, MCDONALD MM, ZHANG L, DURING MJ, LITTLE DG, EISMAN JA, GARDINER EM, YULYANINGSIH E, LIN S, SAINSBURY A, HERZOG H: Novel role of Y1 receptors in the coordinated regulation of bone and energy homeostasis. J Biol Chem 282: 19092-19102, 2007.

BASSETT JH, NORDSTROM K, BOYDE A, HOWELL PG, KELLY S, VENNSTROM B, WILLIAMS GR: Thyroid status during skeletal development determines adult bone structure and mineralization. Mol Endocrinol 21: 1893-1904, 2007a.

BASSETT JH, O'SHEA PJ, SRISKANTHARAJAH S, RABIER B, BOYDE A, HOWELL PG, WEISS RE, ROUX JP, MALAVAL L, CLEMENT-LACROIX P, SAMARUT J, CHASSANDE O, WILLIAMS GR: Thyroid hormone excess rather than thyrotropin deficiency induces osteoporosis in hyperthyroidism. Mol Endocrinol 21: 1095-1107, 2007b.

BASSETT JH, WILLIAMS AJ, MURPHY E, BOYDE A, HOWELL PG, SWINHOE R, ARCHANCO M, FLAMANT F, SAMARUT J, COSTAGLIOLA S, VASSART G, WEISS RE, REFETOFF S, WILLIAMS GR: A lack of thyroid hormones rather than excess thyrotropin causes abnormal skeletal development in hypothyroidism. Mol Endocrinol 22: 501-512, 2008.

BERKNER KL: The vitamin K-dependent carboxylase. Anпи Rev Nutr 25: 127-149, 2005.

BISELLO A, HORWITZ MJ, STEWART AF: Parathyroid hormone-related protein: an essential physiological regulator of adult bone mass. Endocrinology 145: 3551-3553, 2004.

BOYLE WJ, SIMONET WS, LACEY DL: Osteoclast differentiation and activation. Nature 423: 337-342, 2003.

BROADUS AE, MANGIN M, IKEDA K, INSOGNA KL, WEIR EC, BURTIS WJ, STEWART AF: Humoral hypercalcemia of cancer. Identification of a novel parathyroid hormone-like peptide. $N$ Engl J Med 319: 556$563,1988$.

BURGUERA B, HOFBAUER LC, THOMAS T, GORI F, EVANS GL, KHOSLA S, RIGGS BL, TURNER RT: Leptin reduces ovariectomy-induced bone loss in rats. Endocrinology 142: 3546-3553, 2001.

CANALIS E, GIUSTINA A, BILEZIKIAN JP: Mechanisms of anabolic therapies for osteoporosis. $N$ Engl J Med 357: 905-916, 2007. 
CIRMANOVÁ V, BAYER M, STÁRKA L, ZAJÍČKOVÁ K: The effect of leptin on bone - an evolving concept of action. Physiol Res 57 (Suppl 1): S143-S151, 2008.

CLOWES JA, RIGGS BL, KHOSLA S: The role of the immune system in the pathophysiology of osteoporosis. Immunol Rev 208: 207-227, 2005.

CORNISH J, CALLON KE, BAVA U, LIN C, NAOT D, HILL BL, GREY AB, BROOM N, MYERS DE, NICHOLSON GC, REID IR: Leptin directly regulates bone cell function in vitro and reduces bone fragility in vivo. J Endocrinol 175: 405-415, 2002.

COUSIN W, COURSEAUX A, LADOUX A, DANI C, PERALDI P: Cloning of hOST-PTP: the only example of a protein-tyrosine-phosphatase the function of which has been lost between rodent and human. Biochem Biophys Res Commun 321: 259-265, 2004.

DEMAY MB: Mechanism of vitamin D receptor action. Ann N Y Acad Sci 1068: 204-213, 2006.

DOVIO A, PERAZZOLO L, OSELLA G, VENTURA M, TERMINE A, MILANO E, BERTOLOTTO A, ANGELI A: Immediate fall of bone formation and transient increase of bone resorption in the course of high-dose, shortterm glucocorticoid therapy in young patients with multiple sclerosis. J Clin Endocrinol Metab 89: 4923-4928, 2004.

DUCY P, AMLING M, TAKEDA S, PRIEMEL M, SCHILLING AF, BEIL FT, SHEN J, VINSON C, RUEGER JM, KARSENTY G: Leptin inhibits bone formation through a hypothalamic relay: a central control of bone mass. Cell 100: 197-207, 2000.

ELEFTERIOU F, AHN JD, TAKEDA S, STARBUCK M, YANG X, LIU X, KONDO H, RICHARDS WG, BANNON TW, NODA M, CLEMENT K, VAISSE C, KARSENTY G: Leptin regulation of bone resorption by the sympathetic nervous system and CART. Nature 434: 514-520, 2005.

FERRON M, HINOI E, KARSENTY G, DUCY P: Osteocalcin differentially regulates beta cell and adipocyte gene expression and affects the development of metabolic diseases in wild-type mice. Proc Natl Acad Sci USA 105: 5266-5270, 2008.

FU L, PATEL MS, BRADLEY A, WAGNER EF, KARSENTY G: The molecular clock mediates leptin-regulated bone formation. Cell 122: 803-815, 2005.

GALLO J, RAŠKA M, MRÁZEK F, PETŘEK M: Bone remodeling, particle disease and individual susceptibility to periprosthetic osteolysis. Physiol Res 57: 339-349, 2008.

GERDHEM P, ISAKSSON A, AKESSON K, OBRANT KJ: Increased bone density and decreased bone turnover, but no evident alteration of fracture susceptibility in elderly women with diabetes mellitus. Osteoporos Int 16: 1506-1512, 2005.

GREENSPAN SL, RESNICK NM, PARKER RA: Early changes in biochemical markers of bone turnover are associated with long-term changes in bone mineral density in elderly women on alendronate, hormone replacement therapy, or combination therapy: a three-year, double-blind, placebo-controlled, randomized clinical trial. J Clin Endocrinol Metab 90: 2762-2767, 2005.

HARADA S, RODAN GA: Control of osteoblast function and regulation of bone mass. Nature 423: 349-355, 2003.

HASE H, ANDO T, ELDEIRY L, BREBENE A, PENG Y, LIU L, AMANO H, DAVIES TF, SUN L, ZAIDI M, ABE E: TNFalpha mediates the skeletal effects of thyroid-stimulating hormone. Proc Natl Acad Sci USA 103: 12849-12854, 2006.

HAUSCHKA PV, LIAN JB, COLE DE, GUNDBERG CM: Osteocalcin and matrix Gla protein: vitamin K-dependent proteins in bone. Physiol Rev 69: 990-1047, 1989.

HOFBAUER LC, KHOSLA S, DUNSTAN CR, LACEY DL, BOYLE WJ, RIGGS BL: The roles of osteoprotegerin and osteoprotegerin ligand in the paracrine regulation of bone resorption. $J$ Bone Miner Res 15: 2-12, 2000.

HOFBAUER LC, BRUECK CC, SINGH SK, DOBNIG H: Osteoporosis in patients with diabetes mellitus. $J$ Bone Miner Res 22: 1317-1328, 2007.

HOFF AO, CATALA-LEHNEN P, THOMAS PM, PRIEMEL M, RUEGER JM, NASONKIN I, BRADLEY A, HUGHES MR, ORDONEZ N, COTE GJ, AMLING M, GAGEL RF: Increased bone mass is an unexpected phenotype associated with deletion of the calcitonin gene. J Clin Invest 110: 1849-1857, 2002.

HOLLOWAY WR, COLLIER FM, AITKEN CJ, MYERS DE, HODGE JM, MALAKELLIS M, GOUGH TJ, COLLIER GR, NICHOLSON GC: Leptin inhibits osteoclast generation. J Bone Miner Res 17: 200-209, 2002. 
HORWITZ MJ, TEDESCO MB, GUNDBERG C, GARCIA-OCANA A, STEWART AF: Short-term, high-dose parathyroid hormone-related protein as a skeletal anabolic agent for the treatment of postmenopausal osteoporosis. J Clin Endocrinol Metab 88: 569-575, 2003.

INABA M: Secondary osteoporosis: thyrotoxicosis, rheumatoid arthritis, and diabetes mellitus. J Bone Miner Metab 22: 287-292, 2004.

IQBAL J, SUN L, KUMAR TR, BLAIR HC, ZAIDI M: Follicle-stimulating hormone stimulates TNF production from immune cells to enhance osteoblast and osteoclast formation. Proc Natl Acad Sci USA 103: 14925-14930, 2006.

JILKA RL: Molecular and cellular mechanisms of the anabolic effect of intermittent PTH. Bone 40: 1434-1446, 2007.

JILKA RL, WEINSTEIN RS, BELLIDO T, ROBERSON P, PARFITT AM, MANOLAGAS SC: Increased bone formation by prevention of osteoblast apoptosis with parathyroid hormone. J Clin Invest 104: 439-446,1999.

KAMEDA T, MANO H, YUASA T, MORI Y, MIYAZAWA K, SHIOKAWA M, NAKAMARU Y, HIROI E, HIURA K, KAMEDA A, YANG NN, HAKEDA Y, KUMEGAWA M: Estrogen inhibits bone resorption by directly inducing apoptosis of the bone-resorbing osteoclasts. J Exp Med 186: 489-495, 1997.

KARSENTY G: Convergence between bone and energy homeostases: leptin regulation of bone mass. Cell Metab 4: 341-348, 2006.

KATAYAMA Y, BATTISTA M, KAO WM, HIDALGO A, PEIRED AJ, THOMAS SA, FRENETTE PS: Signals from the sympathetic nervous system regulate hematopoietic stem cell egress from bone marrow. Cell 124: 407-421, 2006.

KAWANO H, SATO T, YAMADA T, MATSUMOTO T, SEKINE K, WATANABE T, NAKAMURA T, FUKUDA T, YOSHIMURA K, YOSHIZAWA T, AIHARA K, YAMAMOTO Y, NAKAMICHI Y, METZGER D, CHAMBON P, NAKAMURA K, KAWAGUCHI H, KATO S: Suppressive function of androgen receptor in bone resorption. Proc Natl Acad Sci USA 100: 9416-9421, 2003.

KHOSLA S: Minireview: the OPG/RANKL/RANK system. Endocrinology 142: 5050-5055, 2001.

KHOSLA S: Leptin-central or peripheral to the regulation of bone metabolism? Endocrinology 143: 4161-4164, 2002.

KIM HJ, ZHAO H, KITAURA H, BHATTACHARYYA S, BREWER JA, MUGLIA LJ, ROSS FP, TEITELBAUM SL: Glucocorticoids suppress bone formation via the osteoclast. J Clin Invest 116: 2152-2160, 2006.

KOUSTENI S, CHEN JR, BELLIDO T, HAN L, ALI AA, O'BRIEN CA, PLOTKIN L, FU Q, MANCINO AT, WEN Y, VERTINO AM, POWERS CC, STEWART SA, EBERT R, PARFITT AM, WEINSTEIN RS, JILKA RL, MANOLAGAS SC: Reversal of bone loss in mice by nongenotropic signaling of sex steroids. Science 298 : 843-846, 2002.

KŘÍŽOVÁ J, DOLÍNKOVÁ M, LACINOVÁ Z, SULEK S, DOLEŽALOVÁ R, HOUSOVÁ J, KRAJÍČKOVÁ J, HALUZÍKOVÁ D, BOŠANSKÁ L, PAPEŽOVÁ $H$, HALUZÍK M: Adiponectin and resistin gene polymorphisms in patients with anorexia nervosa and obesity and its influence on metabolic phenotype. Physiol Res 57: 539-546, 2008.

KRONENBERG HM: PTHrP and skeletal development. Ann N Y Acad Sci 1068: 1-13, 2006.

KRUM SA, MIRANDA-CARBONI GA, HAUSCHKA PV, CARROLL JS, LANE TF, FREEDMAN LP, BROWN M: Estrogen protects bone by inducing Fas ligand in osteoblasts to regulate osteoclast survival. EMBO J 27: 535 $545,2008$.

KUSHNER JA, CIEMERYCH MA, SICINSKA E, WARTSCHOW LM, TETA M, LONG SY, SICINSKI P, WHITE MF: Cyclins D2 and D1 are essential for postnatal pancreatic beta-cell growth. Mol Cell Biol 25: 3752-3762, 2005.

LAHARRAGUE P, LARROUY D, FONTANILLES AM, TRUEL N, CAMPFIELD A, TENENBAUM R, GALITZKY J, CORBERAND JX, PENICAUD L, CASTEILLA L: High expression of leptin by human bone marrow adipocytes in primary culture. FASEB J 12: 747-752, 1998.

LEE NK, SOWA H, HINOI E, FERRON M, AHN JD, CONFAVREUX C, DACQUIN R, MEE PJ, MCKEE MD, JUNG DY, ZHANG Z, KIM JK, MAUVAIS-JARVIS F, DUCY P, KARSENTY G: Endocrine regulation of energy metabolism by the skeleton. Cell 130: 456-469, 2007.

LIEDERT A, KASPAR D, BLAKYTNY R, CLAES L, IGNATIUS A: Signal transduction pathways involved in mechanotransduction in bone cells. Biochem Biophys Res Commun 349: 1-5, 2006. 
LIU YJ, SHEN H, XIAO P, XIONG DH, LI LH, RECKER RR, DENG HW: Molecular genetic studies of gene identification for osteoporosis: a 2004 update. J Bone Miner Res 21: 1511-1535, 2006.

LUNDBERG P, ALLISON SJ, LEE NJ, BALDOCK PA, BROUARD N, ROST S, ENRIQUEZ RF, SAINSBURY A, LAMGHARI M, SIMMONS P, EISMAN JA, GARDINER EM, HERZOG H: Greater bone formation of Y2 knockout mice is associated with increased osteoprogenitor numbers and altered Y1 receptor expression. $J$ Biol Chem 282: 19082-19091,2007.

MANOLAGAS SC, KOUSTENI S, JILKA RL: Sex steroids and bone. Recent Prog Horm Res 57: 385-409, 2002.

MARTIN TJ, QUINN JM, GILLESPIE MT, NG KW, KARSDAL MA, SIMS NA: Mechanisms involved in skeletal anabolic therapies. Ann N Y Acad Sci 1068: 458-470, 2006.

MIAO D, HE B, JIANG Y, KOBAYASHI T, SOROCEANU MA, ZHAO J, SU H, TONG X, AMIZUKA N, GUPTA A, GENANT HK, KRONENBERG HM, GOLTZMAN D, KARAPLIS AC: Osteoblast-derived PTHrP is a potent endogenous bone anabolic agent that modifies the therapeutic efficacy of administered PTH 1-34. J Clin Invest 115: 2402-2411, 2005.

MORRISON DF, MAURO LJ: Structural characterization and chromosomal localization of the mouse cDNA and gene encoding the bone tyrosine phosphatase, mOST-PTP. Gene 257: 195-208, 2000.

MUNDY GR, GUISE TA: Hormonal control of calcium homeostasis. Clin Chem 45: 1347-1352, 1999.

NAKAMURA T, IMAI Y, MATSUMOTO T, SATO S, TAKEUCHI K, IGARASHI K, HARADA Y, AZUMA Y, KRUST A, YAMAMOTO Y, NISHINA H, TAKEDA S, TAKAYANAGI H, METZGER D, KANNO J, TAKAOKA K, MARTIN TJ, CHAMBON P, KATO S: Estrogen prevents bone loss via estrogen receptor alpha and induction of Fas ligand in osteoclasts. Cell 130: 811-823, 2007.

NEER RM, ARNAUD CD, ZANCHETTA JR, PRINCE R, GAICH GA, REGINSTER JY, HODSMAN AB, ERIKSEN EF, ISH-SHALOM S, GENANT HK, WANG O, MITLAK BH: Effect of parathyroid hormone (1-34) on fractures and bone mineral density in postmenopausal women with osteoporosis. $N$ Engl J Med 344: 1434-1441, 2001.

OTABE S, YUAN X, FUKUTANI T, WADA N, HASHINAGA T, NAKAYAMA H, HIROTA N, KOJIMA M, YAMADA K: Overexpression of human adiponectin in transgenic mice results in suppression of fat accumulation and prevention of premature death by high-calorie diet. Am J Physiol 293: E210-E218, 2007.

PATEL MS, ELEFTERIOU F: The new field of neuroskeletal biology. Calcif Tissue Int 80: 337-347, 2007.

PRICE PA: Gla-containing proteins of bone. Connect Tissue Res 21: 51-57; discussion 57-60, 1989.

RAŠKA I, JR., BROULíK P: The impact of diabetes mellitus on skeletal health: an established phenomenon with inestablished causes? Prague Med Rep 106: 137-148, 2005.

ROSATO MT, SCHNEIDER SH, SHAPSES SA: Bone turnover and insulin-like growth factor I levels increase after improved glycemic control in noninsulin-dependent diabetes mellitus. Calcif Tissue Int 63: 107-111, 1998.

SATO S, HANADA R, KIMURA A, ABE T, MATSUMOTO T, IWASAKI M, INOSE H, IDA T, MIEDA M, TAKEUCHI Y, FUKUMOTO S, FUJITA T, KATO S, KANGAWA K, KOJIMA M, SHINOMIYA K, TAKEDA S: Central control of bone remodeling by neuromedin U. Nat Med 13: 1234-1240, 2007.

SATO T, KAWANO H, KATO S: Study of androgen action in bone by analysis of androgen-receptor deficient mice. J Bone Miner Metab 20: 326-330, 2002.

SEMENKOVICH CF: Insulin resistance and atherosclerosis. J Clin Invest 116: 1813-1822, 2006.

SEMENKOVICH CF, TEITELBAUM SL: Bone weighs in on obesity. Cell 130: 409-411, 2007.

SCHILLER KR, MAURO LJ: Tyrosine phosphatases as regulators of skeletal development and metabolism. $J$ Cell Biochem 96: 262-277, 2005.

SCHWARTZ AV, SELLMEYER DE: Diabetes, fracture, and bone fragility. Curr Osteoporos Rep 5: 105-111, 2007.

SINGH MK, ELEFTERIOU F, KARSENTY G: Cocaine and amphetamine-regulated transcript may regulate bone remodeling as a circulating molecule. Endocrinology 149: 3933-3941, 2008.

SRIVASTAVA S, TORALDO G, WEITZMANN MN, CENCI S, ROSS FP, PACIFICI R: Estrogen decreases osteoclast formation by down-regulating receptor activator of NF-kappa B ligand (RANKL)-induced JNK activation. J Biol Chem 276: 8836-8840, 2001.

ŠTĚPÁN JJ, ALENFELD F, BOIVIN G, FEYEN JH, LAKATOS P: Mechanisms of action of antiresorptive therapies of postmenopausal osteoporosis. Endocr Regul 37: 225-238, 2003. 
SUN L, PENG Y, SHARROW AC, IQBAL J, ZHANG Z, PAPACHRISTOU DJ, ZAIDI S, ZHU LL, YAROSLAVSKIY BB, ZHOU H, ZALLONE A, SAIRAM MR, KUMAR TR, BO W, BRAUN J, CARDOSO-LANDA L, SCHAFFLER MB, MOONGA BS, BLAIR HC, ZAIDI M: FSH directly regulates bone mass. Cell 125: 247-260, 2006.

TAKEDA S, ELEFTERIOU F, LEVASSEUR R, LIU X, ZHAO L, PARKER KL, ARMSTRONG D, DUCY P, KARSENTY G: Leptin regulates bone formation via the sympathetic nervous system. Cell 111: 305-317, 2002.

TEITELBAUM SL: Osteoclasts: what do they do and how do they do it? Am J Pathol 170: 427-435, 2007.

TEITELBAUM SL, ROSS FP: Genetic regulation of osteoclast development and function. Nat Rev Genet 4: 638-649, 2003.

THOMAS T, GORI F, KHOSLA S, JENSEN MD, BURGUERA B, RIGGS BL: Leptin acts on human marrow stromal cells to enhance differentiation to osteoblasts and to inhibit differentiation to adipocytes. Endocrinology 140: 1630-1638, 1999.

TREMOLLIERES FA, POUILLES JM, RIBOT C: Vertebral postmenopausal bone loss is reduced in overweight women: a longitudinal study in 155 early postmenopausal women. J Clin Endocrinol Metab 77: 683-686, 1993.

WEINSTEIN RS: Glucocorticoid-induced osteoporosis. Rev Endocr Metab Disord 2: 65-73, 2001.

WEINSTEIN RS, JILKA RL, PARFITT AM, MANOLAGAS SC: Inhibition of osteoblastogenesis and promotion of apoptosis of osteoblasts and osteocytes by glucocorticoids. Potential mechanisms of their deleterious effects on bone. J Clin Invest 102: 274-282, 1998.

WOODROW JP, SHARPE CJ, FUDGE NJ, HOFF AO, GAGEL RF, KOVACS CS: Calcitonin plays a critical role in regulating skeletal mineral metabolism during lactation. Endocrinology 147: 4010-4021, 2006.

YAKAR S, ROSEN CJ, BEAMER WG, ACKERT-BICKNELL CL, WU Y, LIU JL, OOI GT, SETSER J, FRYSTYK J, BOISCLAIR YR, LEROITH D: Circulating levels of IGF-1 directly regulate bone growth and density. J Clin Invest 110: 771-781, 2002.

YAMAUCHI T, KAMON J, WAKI H, TERAUCHI Y, KUBOTA N, HARA K, MORI Y, IDE T, MURAKAMI K, TSUBOYAMA-KASAOKA N, EZAKI O, AKANUMA Y, GAVRILOVA O, VINSON C, REITMAN ML, KAGECHIKA H, SHUDO K, YODA M, NAKANO Y, TOBE K, NAGAI R, KIMURA S, TOMITA M, FROGUEL P, KADOWAKI T: The fat-derived hormone adiponectin reverses insulin resistance associated with both lipoatrophy and obesity. Nat Med 7: 941-946, 2001.

ZAIDI M: Skeletal remodeling in health and disease. Nat Med 13: 791-801, 2007.

ZHANG F, CHEN Y, HEIMAN M, DIMARCHI R: Leptin: structure, function and biology. Vitam Horm 71: 345-372, 2005.

ZHANG M, XUAN S, BOUXSEIN ML, VON STECHOW D, AKENO N, FAUGERE MC, MALLUCHE H, ZHAO G, ROSEN CJ, EFSTRATIADIS A, CLEMENS TL: Osteoblast-specific knockout of the insulin-like growth factor (IGF) receptor gene reveals an essential role of IGF signaling in bone matrix mineralization. $J$ Biol Chem 277: 44005-44012, 2002.

ZHANG Y, PROENCA R, MAFFEI M, BARONE M, LEOPOLD L, FRIEDMAN JM: Positional cloning of the mouse obese gene and its human homologue. Nature 372: 425-432, 1994.

ZIKÁN V, ŠTĚPÁN JJ: Plasma type 1 collagen cross-linked C-telopeptide: a sensitive marker of acute effects of salmon calcitonin on bone resorption. Clin Chim Acta 316: 63-69, 2002. 